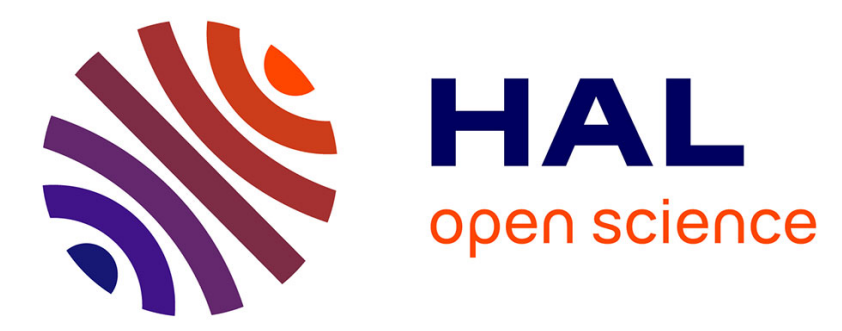

\title{
Hirshfeld Surface Analysis, Crystal Structure and Spectroscopic Studies of a New Cu(II) Halocuprate Salt with Protonated N-Amino-Ethyl-Piperazine Maroua El Glaoui, Maher El Glaoui, Christian Jelsch, C. Ben Nasr
}

\section{- To cite this version:}

Maroua El Glaoui, Maher El Glaoui, Christian Jelsch, C. Ben Nasr. Hirshfeld Surface Analysis, Crystal Structure and Spectroscopic Studies of a New $\mathrm{Cu}(\mathrm{II})$ Halocuprate Salt with Protonated N-Amino-Ethyl-Piperazine. Journal of Structural Chemistry, 2018, 59 (7), pp.1610-1618. 10.1134/S0022476618070120 . hal-02477540

\author{
HAL Id: hal-02477540 \\ https://hal.science/hal-02477540
}

Submitted on 13 Feb 2020

HAL is a multi-disciplinary open access archive for the deposit and dissemination of scientific research documents, whether they are published or not. The documents may come from teaching and research institutions in France or abroad, or from public or private research centers.
L'archive ouverte pluridisciplinaire HAL, est destinée au dépôt et à la diffusion de documents scientifiques de niveau recherche, publiés ou non, émanant des établissements d'enseignement et de recherche français ou étrangers, des laboratoires publics ou privés. 


\title{
A Hirshfeld Surface Analysis, Crystal Structure and Spectroscopic studies of a new $\mathrm{Cu}(\mathrm{II})$ halocuprate salt with protonated $\mathrm{N}$-amino-ethyl-piperazine
}

\author{
Maroua El Glaoui ${ }^{\mathrm{a}}$, Maher El Glaoui ${ }^{*}$, Christian Jelsch ${ }^{\mathrm{c}}$, Chérif Ben Nasr ${ }^{\mathrm{a}}$
}

${ }^{a}$ Laboratoire de Chimie des Matériaux, Faculté des Sciences de Bizerte, Université de Carthage, 7021 Zarzouna, Tunisia.

${ }^{\mathrm{b}}$ Laboratoire de Valorisation des Matériaux Utiles, Centre National des Recherches en Sciences des Matériaux (CNRSM), Technopôle de Borj-Cédria, 8027 Soliman, Tunisia.

${ }^{\mathrm{c}} \mathrm{CRM}^{2}, \mathrm{CNRS}$, Institut Jean Barriol, Université de Lorraine, Vandoeuvre les Nancy, France.

*Corresponding author: elglaouimaher@gmail.com

\begin{abstract}
$\left(\mathrm{C}_{6} \mathrm{H}_{18} \mathrm{~N}_{3}\right)_{4}\left[\mathrm{CuCl}_{5}\right]_{2}\left[\mathrm{CuCl}_{4}\right]_{3} \cdot 1.42 \mathrm{H}_{2} \mathrm{O}$ has been prepared and characterized by various physicochemical techniques. Single crystal X-ray diffraction structural analysis has revealed that the title compound belongs to the orthorhombic system with space group Cmca. Its unit cell dimensions are: $a=24.286$ (2) $\AA, b=14.3082$ (14) $\AA, c=16.6160$ (16) $\AA$, with $Z=4, V=$ $5773.8(10) \AA^{3}$ and its crystal structure was determined and refined down to $R=0.024$ and $w R$ $\left(F^{2}\right)=0.059$. The structure contains three crystallographically independent $\mathrm{Cu}^{2+}$ ions coordinated to chlorine anions in various fashions. $\mathrm{Cu} 1$ is five-coordinated, in a distorted square pyramidal fashion, while $\mathrm{Cu} 2$ and $\mathrm{Cu} 3$ are tetra-coordinated in square planar and distorted tetrahedral fashions, respectively. The entities are interconnected by means of hydrogen bonding $[\mathrm{O}(\mathrm{W})-\mathrm{H} . . . \mathrm{Cl}, \mathrm{N}-\mathrm{H} . . \mathrm{Cl}, \mathrm{C}-\mathrm{H} \ldots \mathrm{Cl}$ and $\mathrm{C}-\mathrm{H} . . \mathrm{O}(\mathrm{W})]$ forming a three-dimensional network. Intermolecular interactions were investigated by Hirshfeld surfaces and the contacts of the eight different chloride atoms were notably compared. The vibrational absorption bands were identified by infrared spectroscopy. The optical study was investigated by UV-vis absorption.
\end{abstract}

Keywords: Organic-inorganic hybrid material; $\mathrm{Cu}(\mathrm{II})$ complex; X-ray diffraction; Coordination compound; Hirshfeld surface; Infrared and Ultraviolet-visible (UV-vis) spectroscopy.

\section{Introduction}

The coordination compounds of metal halides have been interesting due to their unique structural features, for their rich photo-luminescent, magnetic properties, ferroelectric, electronic and interesting optical properties [1 - 17]. Among these compounds, transition metal complexes, especially $\mathrm{Cu}$ (II) complexes, are known to be effective against rheumatoid arthritis and they also show anti-ulcer activity $[18,19]$. The $\mathrm{Cu}$ (II) complexes have different molecular geometries, such as tetrahedral, square planar, square pyramidal and octahedral [20].

One of the best studied groups of copper complexes, both in solution and the solid state, are the halocuprate complexes $[21,22]$. The presence of an active Jahn-Teller effect in the $\mathrm{d}^{9}$ electronic system and the relative flatness of the potential energy surfaces lead to a pronounced plasticity of the metal coordination sphere with a large structural variability and great variety of crystalline architectures with different coordination numbers, geometries, nuclearities and cluster sizes. The halocuprates and their properties are of interest not only in inorganic chemistry but also in fields ranging from solid-state physics to bioinorganic chemistry. Their diversity and ability to easily interconvert into each other make these systems excellent 
candidates for analyzing correlations between structural parameters and magnetic and optical properties $[23,24]$.

\section{Experimental}

\section{1. Chemical preparation}

$\mathrm{CuCl}_{2} \cdot 2 \mathrm{H}_{2} \mathrm{O}$ (1 mmol; $0.17 \mathrm{~g}$ ) was added to an $\mathrm{N}$-amino-ethylpiperazine ( $1 \mathrm{mmol} ; 0.19$

g) solution dissolved in $15 \mathrm{~mL}$ of absolute ethanol. The resulting solution was then acidified with $1 \mathrm{~mL}$ of concentrated $\mathrm{HCl}$ and allowed to evaporate slowly at room temperature. Brown block like crystals of $\left(\mathrm{C}_{6} \mathrm{H}_{18} \mathrm{~N}_{3}\right)_{4}\left[\mathrm{CuCl}_{5}\right]_{2}\left[\mathrm{CuCl}_{4}\right]_{3} \cdot 1.42 \mathrm{H}_{2} \mathrm{O}$ were formed after 6 days (yield, 87.7\%). Anal. Calc.: C, 17.43; H, 4.52; N, 10.17. Found: C, 15.58; H, 4.76; N, 10.31\%.

\section{2. Investigation techniques}

2. 2. 1. X-ray single crystal structural analysis

Single crystals were carefully selected under a microscope and mounted on a Mitegen micromesh mount with the help of a trace of mineral oil. X-ray diffraction data were collected at $100 \mathrm{~K}$ on a Bruker AXS APEXII CCD diffractometer using the $\omega$ scan technique with MoK $\alpha$ radiation $(\lambda=0.7107 \AA)$. Brown single crystals of the composition $\left(\mathrm{C}_{6} \mathrm{H}_{18} \mathrm{~N}_{3}\right)_{4}\left[\mathrm{CuCl}_{5}\right]_{2}\left[\mathrm{CuCl}_{4}\right]_{3} \cdot 1.42 \mathrm{H}_{2} \mathrm{O}\left(M=1652.17 \mathrm{~g} \mathrm{~mol}^{-1}\right)$ are orthorhombic: $a=24.286(2)$ $\AA, b=14.3082$ (14) $\AA, c=16.6160$ (16) $\AA, V=5773.8(10) \AA^{3}$, space group $C m c a, Z=4, D_{\mathrm{x}}$ $\left(\mathrm{Mg} \mathrm{m}^{-3}\right)=1.901, \mu(\mathrm{MoK} \alpha)=2.87 \mathrm{~mm}^{-1}$. The intensities of 27813 reflections were measured in the $\theta$ range: $2.9^{\circ}-32.1^{\circ}$ for data collection by $\omega$-scanning of a low-quality single crystal of $0.55 \times 0.20 \times 0.04 \mathrm{~mm}^{3}\left(R_{\text {int }}=0.033\right)$. The absorption correction was applied empirically using the Multi-scan procedure. The number of independent and observed $[I>2 \sigma(I)]$ reflections are 4890 and 4482 respectively. The data were collected, the unit cell determined, and the data integrated and corrected for absorption and other systematic errors using the Apex 2 suite of programs [25]. SHELXS-97 [26] was used to solve the structure using direct methods and SHELTXL6.14 [27], SHELXL2014 [28] and SHELXLE [29] were used for refinement. The drawings were made with Diamond [30]. The final anisotropic full-matrix least squares resulted in a convergence of the $R\left[F^{2}>2 \sigma\left(F^{2}\right)\right]$ factor at $0.024, w R\left(F^{2}\right)=0.059$, Goodness-of-fit on $F^{2}$ $=1.07$ and $F(000)=3333$.After the completion of the refinement, the maximum and minimum values of the difference electron density are as follows: $\Delta \rho_{\max }=0.67 \mathrm{e} \AA^{-3}$ and $\Delta \rho_{\min }$ is $-0.55 \mathrm{e}$ $\AA^{-3}$.

A water molecule, located on a twofold axis, is partially occupied. Its $\mathrm{H}$ atoms are disordered. The occupancies of the water molecule orientations refined to $0.52(5)$ and $0.19(5)$ respectively. Reflection (200) was affected by the beam stop and was omitted from the refinement.

\section{2. 2. Spectroscopic studies}

The IR spectrum was recorded in the range $4000-400 \mathrm{~cm}^{-1}$ with a "Perkin-Elmer FTIR" 'spectrophotometer 1000 using samples dispersed in spectroscopically pure KBr pressed into a pellet.

Electronic spectrum was recorded on a Perkin-Elmer Lambda 950 spectrophotometer within the range of $250-800 \mathrm{~nm}$.

\section{Results and discussion}

\section{1. X-ray diffraction study}

The structure of the title compound, $\left(\mathrm{C}_{6} \mathrm{H}_{18} \mathrm{~N}_{3}\right)_{4}\left[\mathrm{CuCl}_{5}\right]_{2}\left[\mathrm{CuCl}_{4}\right]_{3} \cdot 1.42 \mathrm{H}_{2} \mathrm{O}$, Figure 1, consists of two $\left[\mathrm{CuCl}_{5}\right]^{3-}$ and three $\left[\mathrm{CuCl}_{4}\right]^{2-}$ discrete anions. All the three N-amino-ethylpiperazine nitrogen atoms are protonated. Thus, to ensure charge balance, the structure contains four organic cations. A crystallization water molecule, located on a twofold axis, is partially occupied, and its $\mathrm{H}$ atoms are disordered. 
The structure contains three crystallographic independent $\mathrm{Cu}^{2+}$ ions, $\mathrm{Cu} 1, \mathrm{Cu} 2$ and $\mathrm{Cu} 3$. As shown in Fig. 2, $\mathrm{Cu} 1$ is coordinated to five chlorine atoms, while $\mathrm{Cu} 2$ and $\mathrm{Cu} 3$ are surrounded by only four anions. The $\mathrm{Cu} 2$ atom, located on a twofold rotation axis, is coordinated in a square planar fashion. The description of the $\left[\mathrm{Cu} 2 \mathrm{Cl}_{4}\right]^{2-}$ entity as square planar is justified by the quasi-equivalent $\mathrm{Cu} 2-\mathrm{Cl} 5$ and $\mathrm{Cu} 2-\mathrm{Cl} 8$ bond distances. The $\mathrm{Cu}-\mathrm{Cl}$ bond lengths fall in the range 2.2676 (5) - 2.3009 (5) $\AA$ and the $\mathrm{Cl}-\mathrm{Cu}-\mathrm{Cl}$ bond angles are $90^{\circ}$ for $\mathrm{cis}$ angles and $180^{\circ}$ for trans angles (Table 1). Analysis of theses angles with the $\tau_{4}$ metric developed by Yang [31] yields a $\tau_{4}$ value of 0 for $\mathrm{Cu} 2$. The $\tau_{4}$ value is calculated as $\frac{[360-(\alpha+\beta)]}{141}$; where $\alpha$ and $\beta$ are two largest angles at the four-coordinate copper(II) atom in question, and the value of zero (0) is indicative of the ideal square-planar geometry, while the value of one (1) indicates ideal tetrahedral geometry. These bond lengths and angles are compatible with the values observed in other homologous derivatives [32 - 34].

Copper atom $\mathrm{Cu} 3$ also occupies a special position. The $\left[\mathrm{Cu} 3 \mathrm{Cl}_{4}\right]^{2-}$ anion assumes a distorted tetrahedral geometry with $D_{2 h}$ symmetry, consistent with the anticipated distortions predicted by the Jahn-Teller effect. These distortions are typically measured by the value of the trans $\mathrm{Cl}-\mathrm{Cu}-\mathrm{Cl}$ angle, which is $136.05(2)^{\circ}$ [35]. The observed yellow-orange color of the title compound is also consistent with the value of the trans angle [36]. This highly distorted tetrahedral geometry is confirmed by the $\tau_{4}$ value of 0.69 .

The coordination geometry around the $\mathrm{Cul}$ center is distorted square pyramidal, with five coordinated chlorine ions. The coordination geometry around the $\mathrm{Cu} 1$ center is distorted square pyramidal given by a $\tau$ value of 0.26 according to Addison's definition ( $\tau=0$, for an ideal square pyramid, and $\tau=1$, for a perfect trigonal bipyramid) [37].

The shortest $\mathrm{Cu} . . \mathrm{Cu}$ distances are 5.422, 5.947 and $7.717 \AA$, the intra-molecular $\mathrm{Cl} . . \mathrm{Cl}$ distances are between 3.23 and $4.60 \AA$ in $\left\{\mathrm{Cu}_{2} \mathrm{Cl}_{4}\right\}, 3.246$ and $4.631 \AA$ in $\left\{\mathrm{Cu}_{1} \mathrm{Cl}_{5}\right\}, 3.435$ and $4.155 \AA$ in $\left\{\mathrm{Cu}_{3} \mathrm{Cl}_{4}\right\}$ units.

In the structural arrangement, the $\left[\mathrm{Cu}_{3} \mathrm{Cl}_{4}\right]^{2-}$ anions are located between the corrugated organic chains and connected to them through $\mathrm{N}-\mathrm{H} . . . \mathrm{Cl}$ and $\mathrm{C}-\mathrm{H} . . . \mathrm{Cl}$ hydrogen bonds to form layers parallel to the (b, c) plane (Fig. 3), situated at $x=\frac{(2 n+1)}{4}$ (Fig. 4). Within the layers, cavities are created extending along the $b$-axis at $(1 / 4,0,1 / 4),(1 / 4,0,3 / 4),(3 / 4,0,1 / 4)$ and $(3 / 4,0,3 / 4)$ (Fig. 4). The crystallization water molecules occupy these cavities through $\mathrm{O}-\mathrm{H} \cdots \mathrm{Cl}$ and $\mathrm{C}$ $\mathrm{H} \cdots \mathrm{O}$ hydrogen bonds (Fig. 4, Table 2). The $\left\{\mathrm{Cu}_{3} \mathrm{Cl}_{4}\right\}$ tetrahedra are interconnected via the $\mathrm{H}_{2} \mathrm{O}$ molecules to form chains at $y=\frac{n}{2}$ (Fig. 5). The $\left[\mathrm{Cu} 2 \mathrm{Cl}_{4}\right]^{2-}$ and the $\left[\mathrm{Cu}_{1} \mathrm{Cl}_{5}\right]^{3-}$ anions, located alternatingly along the $c$-axis direction at $x=\frac{n}{2}$, are inserted between these layers trough N-H...Cl and C-H...Cl hydrogen bonds (Fig. 4).

In the title compound, both the hydrogen atoms attached to nitrogen, carbon and oxygen atoms play an important role in formation of extended molecular association through hydrogen bonding, where the $\mathrm{Cl}$ and $\mathrm{O}$ atoms act as acceptors of hydrogen bonds. Overall, the crystal structure is stabilized via the various types of hydrogen bonding interactions, N-H...Cl, C$\mathrm{H} . . \mathrm{Cl}, \mathrm{C}-\mathrm{H} . . \mathrm{O}$ and $\mathrm{O}-\mathrm{H} . . \mathrm{Cl}$, and the inclusion of a water molecule seems essential for the stabilization of the molecular packing structures. The hydrogen-bonding metrics are summarized in Table 2.

The conformations of piperazindiium six-membered rings can be described in terms of Cremer and Pople puckering coordinates [38], i.e., evaluating the parameters $Q$ (total puckering amplitude), $q_{2}, q_{3}, \theta$ and $\varphi$. The calculated values for the N1-C1-C2-N2-C4-C3 ring are as

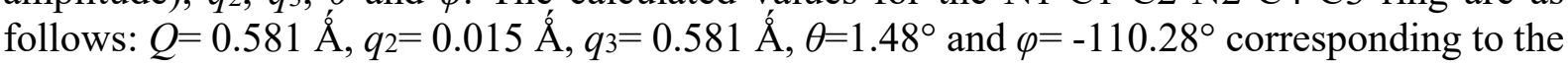
most stable chair conformation. 


\section{2. Hirshfeld surface and enrichment ratio}

Analysis of intermolecular interactions using the Hirshfeld surface-based tools represents a major tool to understand the crystal packing [39]. The Hirshfeld surfaces were computed with software MoProViewer [40] around the different independent entities present in the crystal structure. The multiplicity of some atoms in special positions $\left(\mathrm{Cu}\right.$ and $\left.\mathrm{Cl}^{-}\right)$was taken into account in the addition of the different surfaces. The enrichment ratios [41] of the contacts between the different chemical species enable to highlight the contacts that are favored and are likely to be the crystal packing driving force. Hydrogen atoms bound to carbon ( $\mathrm{Hc})$ are distinguished from the polar hydrogen atoms bound to oxygen or nitrogen (Hno).

The $\mathrm{H}$ and $\mathrm{Cl}^{-}$chemical species contribute to the vast majority of the Hirshfeld surface as both represent more than $40 \%$ presence. There are three major contacts with their surface $S_{X Y}$ larger than $23 \%$, and globally they constitute more than three quarters of the contact surface: $\mathrm{Hc} . . \mathrm{Cl}$, Hno... Cl and $\mathrm{Cu} . . . \mathrm{Cl}$. Their enrichment ratios are all larger than unity and are in accordance with their respective strength. The salt bridges $\mathrm{Cu}^{2+} \ldots \mathrm{Cl}^{-}$are strong electrostatic interactions which are enriched at $E=2.34$ (Table 3), followed by the strong hydrogen bonds $\mathrm{Hn} / \mathrm{o} . . . \mathrm{Cl}^{-}$. Even the weak $\mathrm{H}$-bonds $\mathrm{Hc}_{\text {. . . }} \mathrm{Cl}^{-}$are still favored at $E=1.45$. This suggests that these three major and enriched contacts are the driving force in the crystal packing formation. The nature of the interactions involving the eight independent chloride atoms is illustrated in Figs. 6 and 7 . The $\mathrm{Cl}^{-}$anions assume $32 \% \pm 11 \%$ of the surface involved in a salt bridge with $\mathrm{Cu}^{2+}$

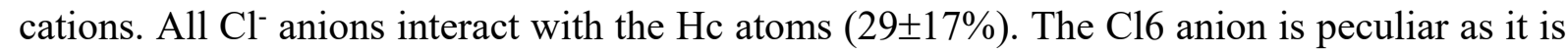
surrounded by a largely hydrophobic environment reaching $65 \%$ of the surface, and does not form any $\mathrm{Cl}^{-} \ldots \mathrm{H}-\mathrm{N}$ nor $\mathrm{Cl}^{-} \ldots \mathrm{H}-\mathrm{O}$ hydrogen bonds. The $11 \% \pm 4 \%$ of $\mathrm{Cl}^{-} \ldots \mathrm{Cl}^{-}$contacts are a consequence of the proximity of the chloride atoms that coordinate the two cupper atoms.

The Hc...Hc contacts are rare in this crystal and are significantly under-represented with $E=0.50$. The hydrophobic Hc...Hc contacts are disfavored as the organic cations hardly interact with themselves and are mainly surrounded by chlorine atoms. The cations are separated by layers built of anions $\mathrm{CuCl}_{\mathrm{x}}$, which are parallel to the (b, c) plane (Fig. 4). All other self-contacts that involve chemical types with a significant charge $\left(\mathrm{Cl}^{-}, \mathrm{Cu}^{2+}, \mathrm{Hn} / \mathrm{o}^{\delta^{+}}, \mathrm{O}^{\delta-}\right)$ are strongly avoided. The copper atom $\mathrm{Cu} 3$ is coordinated by only four chloride atoms, the remaining copper surface interacts weakly with the Hc atoms of the cation.

\section{3. IR spectroscopy}

To gain more information on the crystal structure, we have undertaken a vibrational study using infrared spectroscopy. The experimental vibrational spectrum is shown in Fig. 8. The assignments of the observed bands are essentially based on comparisons with data previously reported for similar compounds $[42,43]$.

Heterocyclic compounds containing an N-H group exhibit N-H stretching absorption in the region from 3500 to $3200 \mathrm{~cm}^{-1}$. In the present work, bands between 3520 and $3420 \mathrm{~cm}^{-1}$ are assigned to the stretching vibrations of the $\mathrm{O}-\mathrm{H}$ and $\mathrm{N}-\mathrm{H}$ groups. The bands of medium intensities at 3107,3019 and $2867 \mathrm{~cm}^{-1}$ have been assigned to the $\mathrm{C}-\mathrm{H}$ stretching modes. The strong band observed at $2729 \mathrm{~cm}^{-1}$ was attributed to $v_{\text {sym }}\left(\mathrm{NH}_{2}{ }^{+}\right)$. The band at $1624 \mathrm{~cm}^{-1}$ was assigned to the $\mathrm{O}-\mathrm{H}$ in-plane deformation. The bands at 1501,1455 and $1400 \mathrm{~cm}^{-1}$ were assigned to $\mathrm{CH}_{3}$ and $\mathrm{CH}_{2}$ deformation modes. The bands of medium intensities at 1369,1227 and $1193 \mathrm{~cm}^{-1}$ were assigned to $\mathrm{C}-\mathrm{N}$ stretching. The bands at 1137,1041 and $983 \mathrm{~cm}^{-1}$ were attributed to asymmetric and symmetric C-C stretching modes. Finally the infrared bands observed in the range $940-500 \mathrm{~cm}^{-1}$ were assigned to CCN group deformation vibrations.

\section{4. UV-Visible spectroscopy}

The solid state electronic spectrum of the title compound is shown in Fig. 9. Two strong absorptions appear at 275 and $625 \mathrm{~nm}$. The first band is assigned to chloride to copper charge 
transfer $\mathrm{Cl} \rightarrow \mathrm{Cu}$ LMCT transition [44]. The second band, in the visible region, corresponds to $\mathrm{Cu} \rightarrow \mathrm{Cl}$ MLTC and intra-ligand $\mathrm{CT}$ transition. The transition may be assigned as the $d_{x y}, d_{x z}, d_{y z}, d_{z^{2}} \rightarrow d_{x^{2}-y^{2}}[45]$.

\section{Conclusions}

We have obtained a new halocuprate salt, $\left(\mathrm{C}_{6} \mathrm{H}_{18} \mathrm{~N}_{3}\right)_{4}\left[\mathrm{CuCl}_{5}\right]_{2}\left[\mathrm{CuCl}_{4}\right]_{3} \cdot 1.42 \mathrm{H}_{2} \mathrm{O}$ crystals, which crystallize in orthorhombic $\mathrm{Cmca}$ space group. In the structure, the coordination polyhedra around the three crystallographically independent $\mathrm{Cu}(\mathrm{II})$ atoms are different. $\mathrm{Cu} 1$, $\mathrm{Cu} 2$ and $\mathrm{Cu} 3$ have distorted square pyramidal, square planar and distorted tetrahedral environments, respectively. The crystal structure is stabilized via the various types of hydrogen bonding interactions, $\mathrm{N}-\mathrm{H} . . . \mathrm{Cl}, \mathrm{C}-\mathrm{H} \ldots \mathrm{Cl}, \mathrm{C}-\mathrm{H} \ldots \mathrm{O}$ and $\mathrm{O}-\mathrm{H} . . \mathrm{Cl}$. The Hirshfeld surface analysis reveals that the driving force in the crystal packing is constituted by the interactions of the chloride atoms with $\mathrm{Cu}$, Hno and $\mathrm{Hc}$ species. They constitute a large majority of the Hirshfeld contact surface and they are all three significantly enriched. The vibrational absorption bands were identified by infrared spectroscopy. The UV-vis shows two bands. The first one, in the near UV region, at $275 \mathrm{~nm}$ is attributed to the chloride to copper charge transfer transition. The second one, in the visible domain, at $625 \mathrm{~nm}$ is assigned to the copper to chlorine intra-ligand charge transfer transition.

\section{Highlights}

- A new organic-inorganic hybrid material $\left(\mathrm{C}_{6} \mathrm{H}_{18} \mathrm{~N}_{3}\right)_{4}\left[\mathrm{CuCl}_{5}\right]_{2}\left[\mathrm{CuCl}_{4}\right]_{3} \cdot 1.42 \mathrm{H}_{2} \mathrm{O}$ crystals were synthesized.

- The crystal X-ray structure has been determined.

- Hirshfeld surface analysis was used to evaluate intermolecular contacts.

- Vibrational properties were studied by infrared spectroscopy.

- The UV-Vis spectrum shows two absorption peaks at 275 and $625 \mathrm{~nm}$.

\section{Supplementary material}

Crystallographic data for the structural analysis have been deposited at the Cambridge Crystallographic Data Centre, CCDC No 1455800. These data can be obtained free of charge via http://www.ccdc.cam.ac.uk/conts/retrieving.html, or from the CCDC, 12 Union Road, Cambridge, CB2 1EZ, UK: fax: (+44) 01223-336-033; e-mail: deposit@ccdc.cam.ac.

\section{Acknowledgment}

Thanks to Professor Matthias Zeller of Youngstown State University (USA) for his fruitful collaboration. The diffractometer was funded by NSF grat 0087120, by Ohio Board of Reagents grant CAP-491, and by YSU.

\section{References}

[1] J. D. Martin, B. R. Leafblad, The Hydrogen-Bonded Framework of the First AntiZeotype: $\left[\left\{\left(\mathrm{H}_{2} \mathrm{NEt}_{2}\right)_{2}\right\}_{2}\left(\mathrm{CuCl}_{4}\right)\right]\left[\mathrm{AlCl}_{4}\right]$, Angew. Chem. 37, 3318 - 3320 (1998).

[2] C. R. Rice, S. Onions, N. Vidal, J. D. Wallis, M.-C. Senna, M. Pilkington, H. StoeckliEvans, The coordination chemistry of 3,3'-diamino-2,2'-bipyridine and its dicationexploring the role of the amino groups by X-ray crystallography, Eur. J. Inorg. Chem. 8, 1985 - 1997 (2002).

[3] R. Bhattacharya, M. S. Ray, R. Dey, L. Righi, G. Bocelli, A. Ghosh, Synthesis, crystal structure and thermochromism of benzimidazolium tetrachlorocuprate: $\left(\mathrm{C}_{7} \mathrm{H}_{7} \mathrm{~N}_{2}\right)_{2}\left[\mathrm{CuCl}_{4}\right]$, Polyhedron 21, 2561 - 2565 (2002). 
[4] A. Weselucha-Birczynska, C. Paluszkiewicz, Analysis of tetrachlorocuprate(II) and tetrachlorocobaltate(II) anion vibrations in their compounds with cinchonine. FT-IR and Raman study, J. Mol. Struct. 614, 339 - 343 (2002).

[5] S. F. Haddad, M. A. AlDamen, R. D. Willet, The role of non-classical supramolecular interactions in the structures of 2-amino-4, 6-dimethylpyridinium tetrahalocuprate (II) salts, Inorg. Chim. Acta 359, 424 - 432 (2006).

[6] A. R. Parent, C. P. Landee, M. M. Turnbull, Transition metal halide salts of Nmethylmorpholine: Synthesis, crystal structures and magnetic properties of $\mathrm{N}$ methylmorpholinium salts of copper(II), cobalt(II) and manganese(II), Inorg. Chim. Acta 360, 1943 - 1953 (2007).

[7] F. A. Cotton, L. M. Daniels, P. I. Huang, Correlation of structure and triboluminescence for tetrahedral manganese(II) compounds, Inorg. Chem. 40, 3576 - 3578 (2001).

[8] M. Czugler, L. Kótai, B. Sreedhar, A. Rockenbauer, I. Gács, S. Holly, The Effect of HCl on the Copper(II) Chloride/Pyridine/Water System: Synthesis, Properties and Crystal Structure of $\left[(\mathrm{pyH})_{2} \mathrm{CuCl}_{4}\right]$ and $\left[(\mathrm{pyH})_{2} \mathrm{Cu}_{3} \mathrm{Cl}_{8}\left(\mathrm{H}_{2} \mathrm{O}\right)_{2}\right]_{\mathrm{n}}$, Eur. J. Inorg. Chem. 12, 3298 - 3304 (2002).

[9] N. Lah, R. Clérac, $\mathrm{Cu}(\mathrm{II})$ coordination polymers incorporating 3-aminopyridine and flexible aliphatic dicarboxylate ligands: Synthesis, structure and magnetic properties, Polyhedron 28, 2466 - 2472 (2009).

[10] B. J. Prince, M. M. Turnbull, R. D. Willett, Copper(II) Halide Complexes of 2Aminopyrimidines: Crystal Structures of [(2-aminopyrimidine $\left.)_{n} \mathrm{CuCl}_{2}\right](\mathrm{n}=1,2)$ and $(2$ amino-5-bromopyrimidine) ${ }_{2} \mathrm{CuBr}_{2}$, J. Coord. Chem. 56, 441 - 452 (2003).

[11] S. N. Herringer, M. M. Turnbull, C. P. Landee, J. L. Wikaira, Synthesis, structure, and magnetic properties of bis (3-amino-2-chloropyridinium)tetrahalocuprate(II) [halide = $\mathrm{Cl}$ or Br], J. Coord. Chem. 62, 863 - 875 (2009).

[12] M. Zdanowska-Fraczek, K. Holderna-Natkaniec, Z. J. Fraczek, R. Jakubas, Molecular dynamics and electrical conductivity of $\left(\mathrm{C}_{3} \mathrm{~N}_{2} \mathrm{H}_{5}\right)_{5} \mathrm{Bi}_{2} \mathrm{Cl}_{11}$, Solid State Ion 180, 9 - 12 (2009).

[13] I. Chaabane, F. Hlel, K. Guidara, Electrical study by impedance spectroscopy of the new compound $\left[\mathrm{C}_{12} \mathrm{H}_{17} \mathrm{~N}_{2}\right]_{2} \mathrm{CdCl}_{4}$, J. Alloys Compd. 461, 495 - 500 (2008).

[14] K. Sakai, M. Takemura, Y. Kawabe, Lead chloride-based layered perovskite incorporated with an excited state intramolecular proton transfer dye, J. Lumin. 130, 2505 - 2507 (2010).

[15] K. Pradeesh, G. Sharachandar Yadav, M. Singh, G. Vijaya Prakash, Synthesis, structure and optical studies of inorganic-organic hybrid semiconductor, $\mathrm{NH}_{3}\left(\mathrm{CH}_{2}\right){ }_{12} \mathrm{NH}_{3} \mathrm{PbI}_{4}, J$. Mater. Chem. Phys. 124, 44 - 47 (2010).

[16] M. Bujak, J. Zaleski, High temperature ferro-paraelectric phase transition in tris(trimethylammonium) nonachlorodiantimonate(III) (TMACA) studied by X-ray diffraction method, Cryst. Eng. 4, 241 - 252 (2001).

[17] P. Gomez-Romero, Hybrid Organic-Inorganic Materials In Search of Synergic Activity, Adv. Mater. 13, 163 - 174 (2001).

[18] John R. J. Sorenson, Copper chelates as possible active forms of the antiarthritic agents, J. Med. Chem. 19, 135 - 148 (1976). 
[19] P. M. May, D. R. Williams, Role of low molecular weight copper complexes in the control of rheumatoid Arthritis, Met. Ions Biol. Syst., Helmut Sigel: New York, NY, USA, 12, 283 - 317 (1981).

[20] P. S. Subramanian, D. Srinivas, Synthesis, spectral characterization and magnetic properties of dicarboxylato-bridged dinuclear copper(II) complexes with npyridylsalicylidenaminato ligand, Polyhedron 15, 985 - 989 (1996).

[21] J. Sertucha, A. Luque, F. Lloret, P. Román, Crystal structure, magnetic properties and ESR studies of (4-apyH $)_{4}\left[\left(\mathrm{Cu}_{11} \mathrm{Br}_{4}\right)\left(\mathrm{Cu}_{1} \mathrm{Br}_{2}\right)_{2}\right.$ : A novel $\mathrm{Cu}(\mathrm{II}) / \mathrm{Cu}(\mathrm{I})$ system containing bromocuprate(I) chains and isolated tetrabromocuprate(II) anions, Polyhedron 17, 3875 - 3880 (1998).

[22] V. Fernandez, M. Moran, M. T. Gutiérrez-Rios, C. Foces-Foces, F. H. Cano, EPR and $\mathrm{X}$-ray structural study of some tetrahalocuprates $\mathrm{CuX}_{4}{ }^{2-}(\mathrm{X}=\mathrm{Cl}, \mathrm{Br})$ of protonated ammines with thermochromic properties, Inorg. Chim. Acta 128, 239 - 243 (1987).

[23] P. Román, J. Sertucha, A. Luque, L. Lezama, T. Rojo, Magneto-structural studies and thermal analysis of the 4-aminopyridinium tetrabromocuprate(II) monohydrate, Polyhedron 15, 1253 - 1262 (1996).

[24] K. M. Guckian, B. A. Schweitzer, R. X. Ren, C. J. Sheils, D. C. Tahmassebi, E. T. Kool, Factors Contributing to Aromatic Stacking in Water: Evaluation in the Context of DNA, J. Am. Chem. Soc. 122, 2213 - 2222 (2000).

[25] Bruker Apex2, Advanced X-ray Solutions Bruker AXS Inc., Madison, Wisconsin, USA (2009).

[26] G. M. Sheldrick, A short history of SHELX, Acta Cryst. A64, 112 - 122 (2008).

[27] Bruker Advanced X-ray Solutions, SHELXTL (Version 6.14), Bruker AXS Inc., Madison, Wisconsin, USA, (2003).

[28] G. M. Sheldrick, SHELXL2013, University of Göttingen, Germany (2013).

[29] C. B. Hübschle, G. M. Sheldrick, B. Dittrich, ShelXle: a Qt graphical user interface for SHELXL, J. Appl. Cryst. 44, 1281 - 1284 (2011).

[30] K. Brandenburg, Diamond Version 2.0 Impact GbR, Bonn., Germany (1998).

[31] L. Yang, D. R. Powell, R. P. Houser, Structural variation in copper(I) complexes with pyridylmethylamide ligands: structural analysis with a new four-coordinate geometry index $\tau$, Dalton Trans. 955 - 964 (2007).

[32] A. Kessentini, M. Belhouchet, Y. Abid, C. Minot, T. Mhiri, Crystal structure, vibrational studies, optical properties and DFT calculation of bis 2-aminobenzothiazolium tetrachloridocuprate, Spectrochim. Acta A 122, 476 - 481 (2014).

[33] D.-H He, Y.-Y Di, Z.-C Tan, F.-F Yi, W.-Y Dan, Y.-P Liu, Crystal structures and thermochemistry on phase change materials $\left(\mathrm{n}-\mathrm{C}_{\mathrm{n}} \mathrm{H}_{2 \mathrm{n}+1} \mathrm{NH}_{3}\right)_{2} \mathrm{CuCl}_{4}(\mathrm{~s})(\mathrm{n}=14$ and 15), Sol. Energy Mat. Sol. Cells 95, 2897 - 2906 (2011).

[34] E. P. Aldrich, K. A. Bussey, J. R. Connell, E. F. Reinhart, K. D. Oshin, B. Q. Mercado, A. G. Oliver, Crystal structure of the thermochromic bis(diethylammonium) tetrachloridocuprate(II) complex, Acta Cryst. E72, 40 - 43 (2016).

[35] A. Kessentini, M. Belhouchet, J. J. Suñol, Y. Abid, T. Mhiri, Synthesis, structural, photoluminescence, vibrational and DFT investigation of the bis (4-aminopyridinium) tetrachloridocuprate(II) monohydrate, J. Lumin. 149, 341 - 347 (2014). 
[36] G. R. Willey, M. Ravindran, M. G. B. Drew, A study of the copper(II) chloride trimethylamine system - crystal and molecular - structure of bis[trimethyl(chloromethyl)ammonium]tetrachlorocuprate(II), $\left[\mathrm{Me}_{3} \mathrm{NCH}_{2} \mathrm{Cl}_{2}\left[\mathrm{CuCl}_{4}\right]\right.$, Inorg. Chim. Acta 188, 159 - 162 (1991).

[37] A. W. Addison, T. Nageswara Rao, J. Recdijk, J. van Rijn, G. C. Verschoor, Synthesis, structure, and spectroscopic properties of copper(II) compounds containing nitrogensulphur donor ligands; the crystal and molecular structure of aqua[1,7-bis $(N$ methylbenzimidazol-2'-yl)-2,6-dithiaheptane]copper(II) perchlorate, J. Chem. Soc., Dalton Trans. 1349 - 1356 (1984).

[38] D. Cremer, General definition of ring puckering coordinates, J. Am. Chem. Soc. 97, 1354 - 1358 (1975).

[39] M. A. Spackman, D. Jayatilaka, Hirshfeld surface analysis, Cryst. Eng. Comm. 11, 19 32 (2009).

[40] B. Guillot, E. Enrique, L. Huder, C. Jelsch, MoProViewer: a tool to study proteins from a charge density science perspective, Acta Cryst. A70, C279 (2014).

[41] C. Jelsch, S. Soudani, C. Ben Nasr, Likelihood of atom-atom contacts in crystal structures of halogenated organic compounds, IUCr J. 2, 327 - 340 (2015).

[42] S. Gunasekaran, B. Anita, Spectral investigation and normal coordinate analysis of piperazine, Indian J. Pure Appl. Phys. 46, 833 - 838 (2008).

[43] J. Orive, E. S. Larrea, R. F. De Luis, M. Iglesias, J. L. Mesa, T. Rojo, M. I. Arriortua, Amine templated open-framework vanadium(III) phosphites with catalytic properties, Dalton Trans. 42, 4500 - 4512 (2013).

[44] P. F. Raphael, E. Manoj, M. R. P. Kurup, Copper(II) complexes of N(4)-substituted thiosemicarbazones derived from pyridine-2-carbaldehyde:Crystal structure of a binuclear complex, Polyhedron 26, 818 - 828 (2007).

[45] B. F. Hathaway, in Comprehensive Coordination Chemistry, ed. G. Wilkinson, Pergamon, Oxford, 1st edn., 5, 533 - 774 (1987). 


\section{Figure Captions}

Fig. 1

A view of the asymmetric unit in the crystal structure of the title compound showing the atom-numbering scheme and displacement ellipsoids drawn at the $50 \%$ probability level. The dotted lines indicate hydrogen bonds.

Fig. 2

The coordination of $\mathrm{Cu}$ in $\left(\mathrm{C}_{6} \mathrm{H}_{18} \mathrm{~N}_{3}\right)_{4}\left[\mathrm{CuCl}_{5}\right]_{2}\left[\mathrm{CuCl}_{4}\right]_{3} 1.42\left(\mathrm{H}_{2} \mathrm{O}\right)$.

Fig. 3

Projection, along the $a$-axis, of a layer in the structure of the title compound. The dotted lines indicate hydrogen bonds.

Fig. 4

Projection of the crystal structure of $\left(\mathrm{C}_{6} \mathrm{H}_{18} \mathrm{~N}_{3}\right)_{4}\left[\mathrm{CuCl}_{5}\right]_{2}\left[\mathrm{CuCl}_{4}\right]_{3} 1.42\left(\mathrm{H}_{2} \mathrm{O}\right)$ in the $(\mathbf{a}, \mathbf{c})$ plane, with hydrogen bonds indicated as dashed lines.

Fig. 5

Chains between $\mathrm{Cu}_{3} \mathrm{Cl}_{4}{ }^{2-}$ and water molecules in $\left(\mathrm{C}_{6} \mathrm{H}_{18} \mathrm{~N}_{3}\right)_{4}\left[\mathrm{CuCl}_{5}\right]_{2}\left[\mathrm{CuCl}_{4}\right]_{3} 1.42\left(\mathrm{H}_{2} \mathrm{O}\right)$. The dotted lines indicate hydrogen bonds.

Fig. 6

View of the Hirshfeld surface around the eight independent chloride atoms in the crystal. The surface is colored according to the exterior atom contributing most to the spherical electron density. Cl: Green, Hc: grey, Ho/n: light blue, C: black, N: blue, O: red, $\mathrm{Cl}$ : green and $\mathrm{Cu}$ : orange. The organic cation and water molecules of the asymmetric are also show.

Fig. 7

Nature of interactions of the eight chloride atoms. The average value and standard deviation of each contact type is shown on the right.

Fig. 8

Infrared spectra of $\left(\mathrm{C}_{6} \mathrm{H}_{18} \mathrm{~N}_{3}\right)_{4}\left[\mathrm{CuCl}_{5}\right]_{2}\left[\mathrm{CuCl}_{4}\right]_{3} 1_{1.42}\left(\mathrm{H}_{2} \mathrm{O}\right)$.

Fig. 9

The UV-Vis spectrum of $\left(\mathrm{C}_{6} \mathrm{H}_{18} \mathrm{~N}_{3}\right)_{4}\left[\mathrm{CuCl}_{5}\right]_{2}\left[\mathrm{CuCl}_{4}\right]_{3} 1.42\left(\mathrm{H}_{2} \mathrm{O}\right)$. 


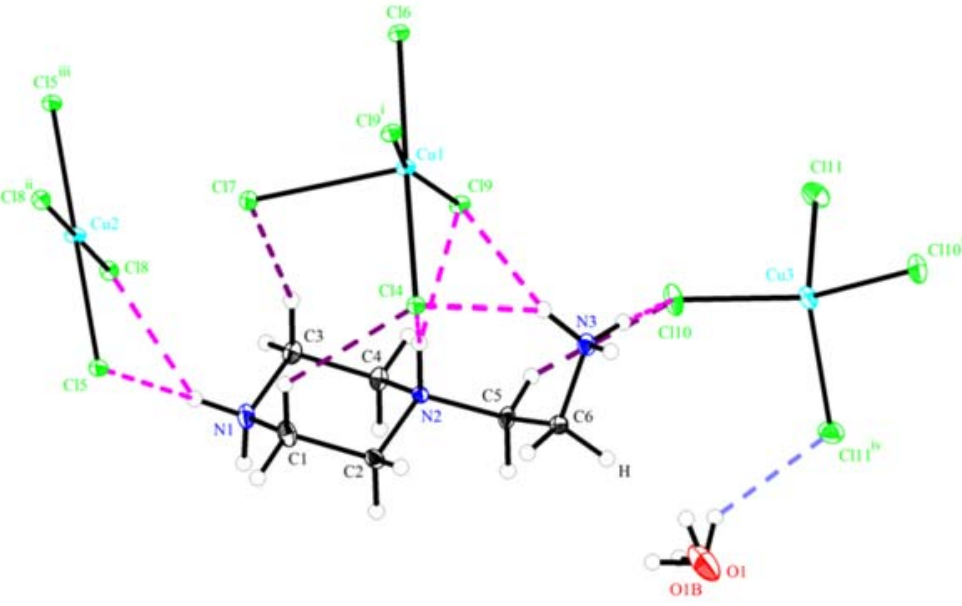

Fig. 1
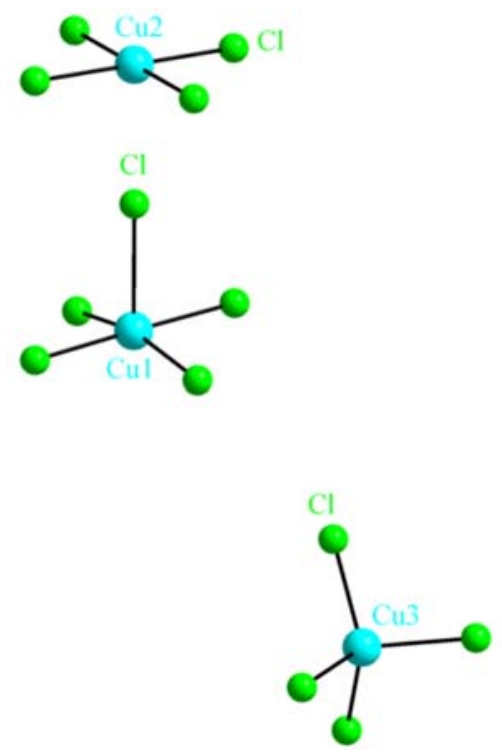

Fig. 2

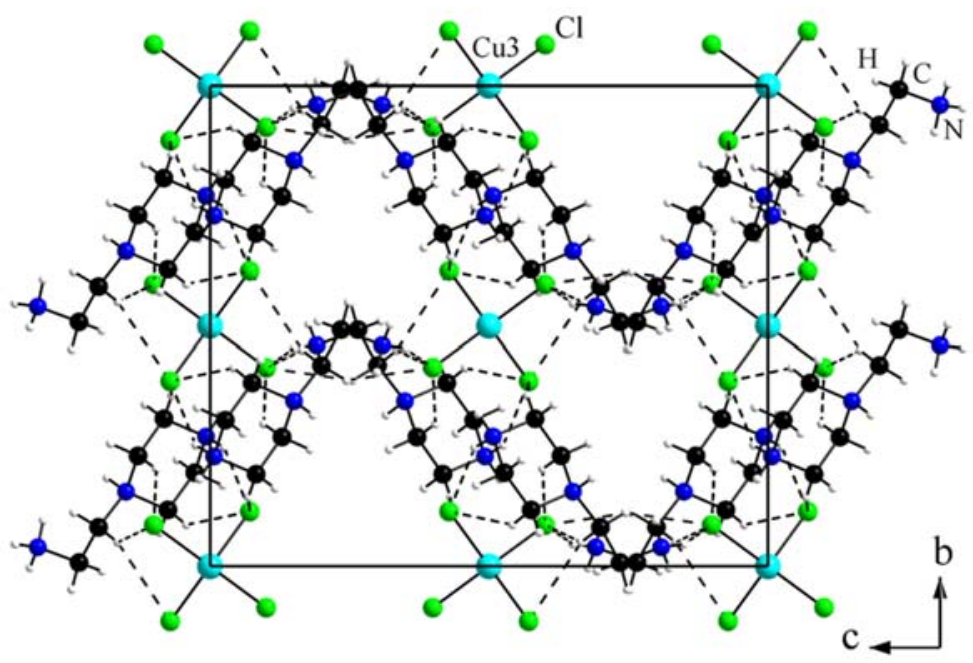

Fig. 3 


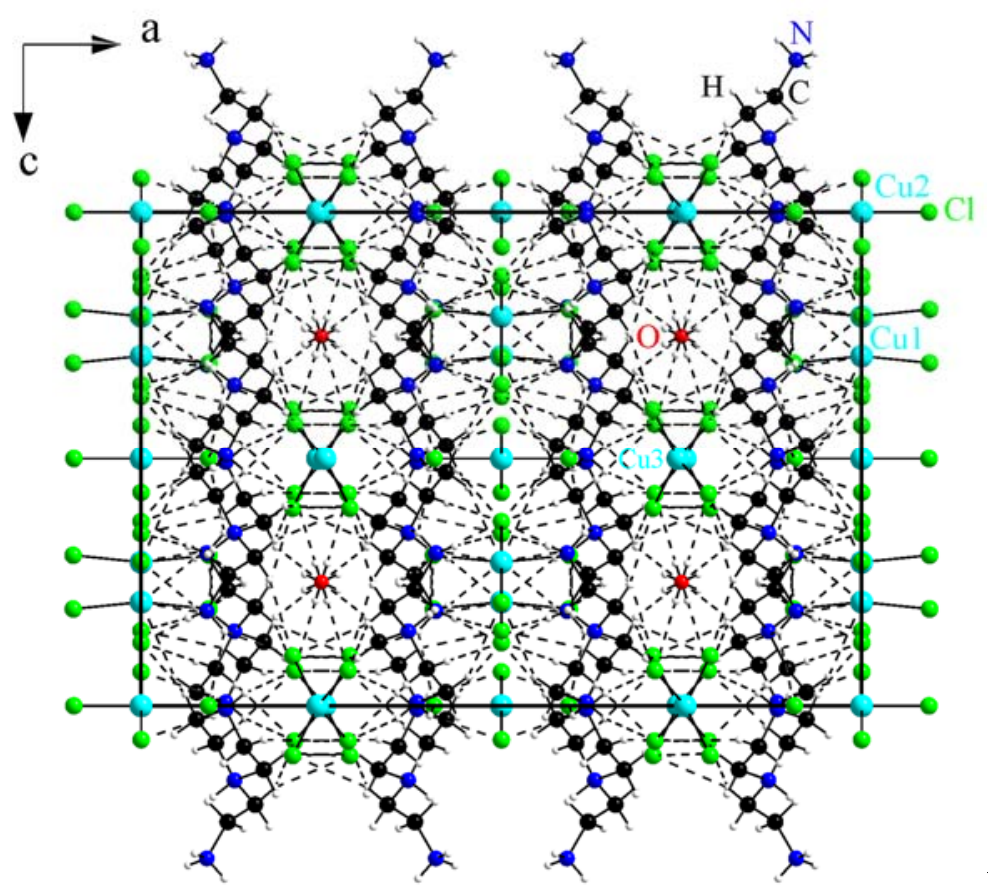

Fig. 4
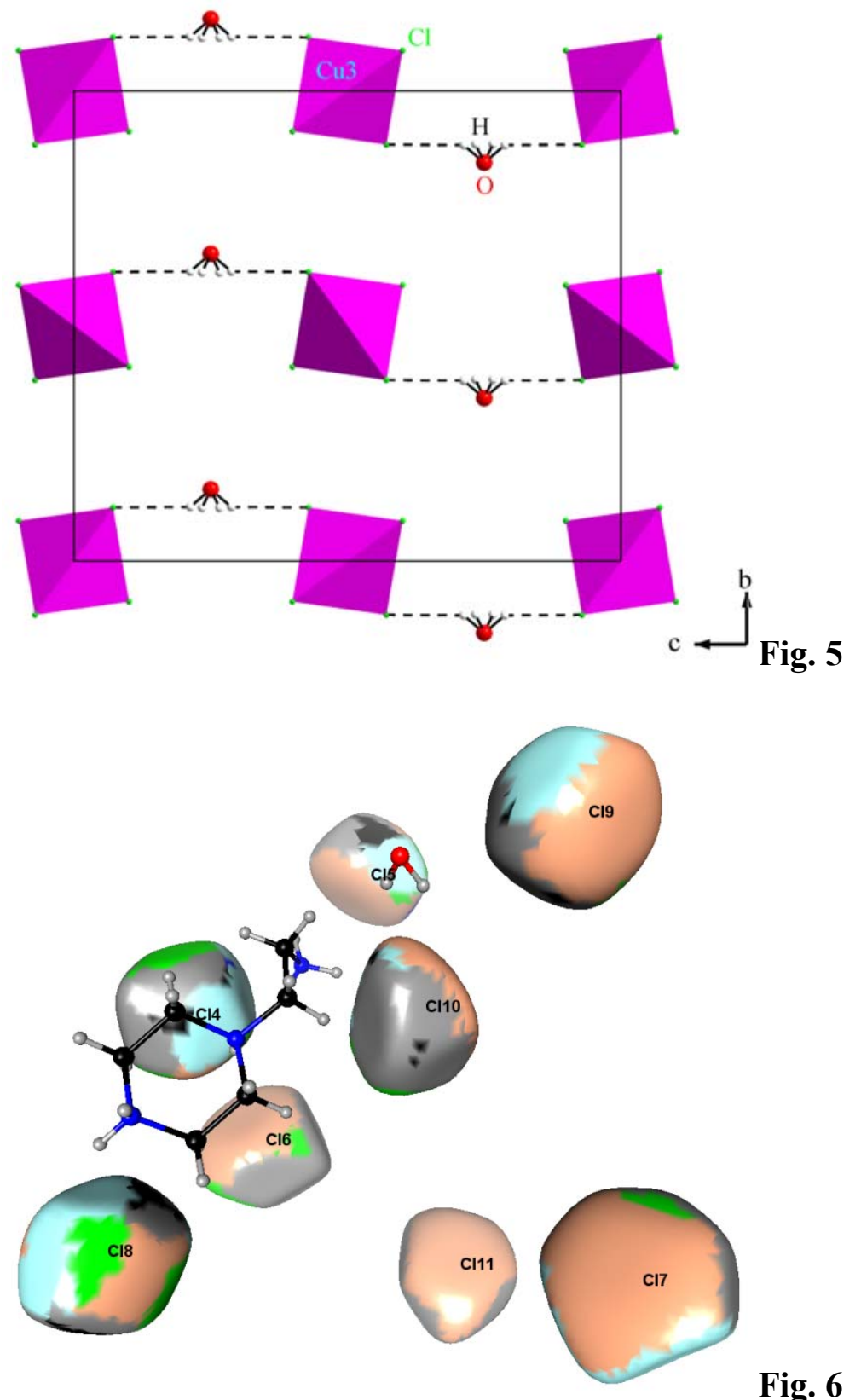


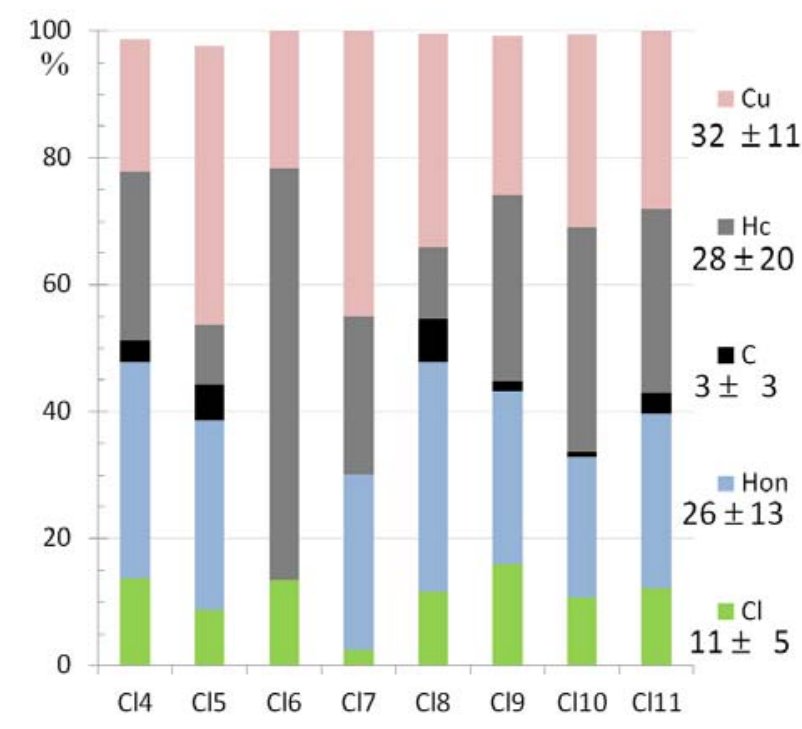

Fig. 7

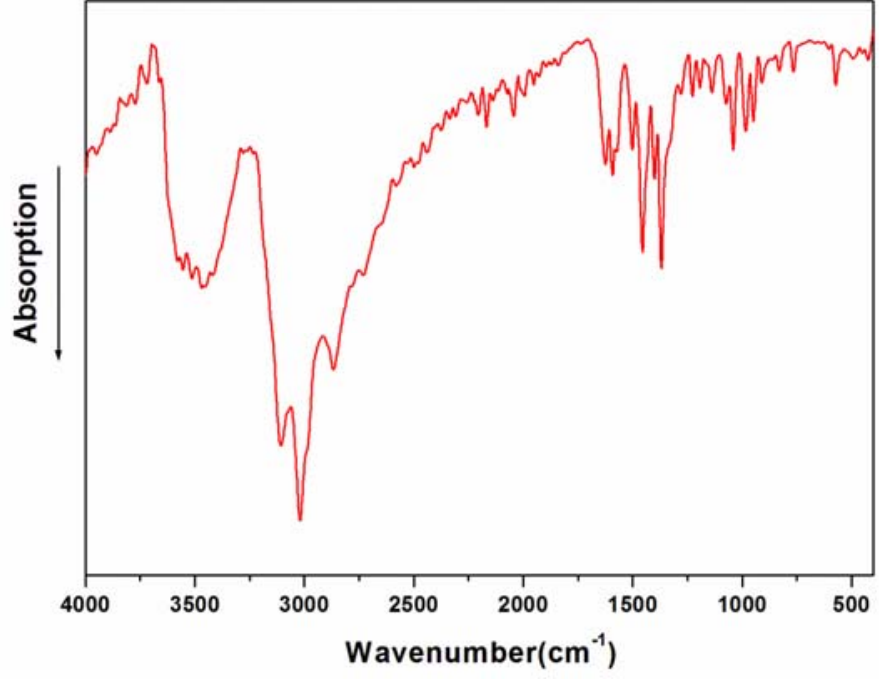

Fig. 8

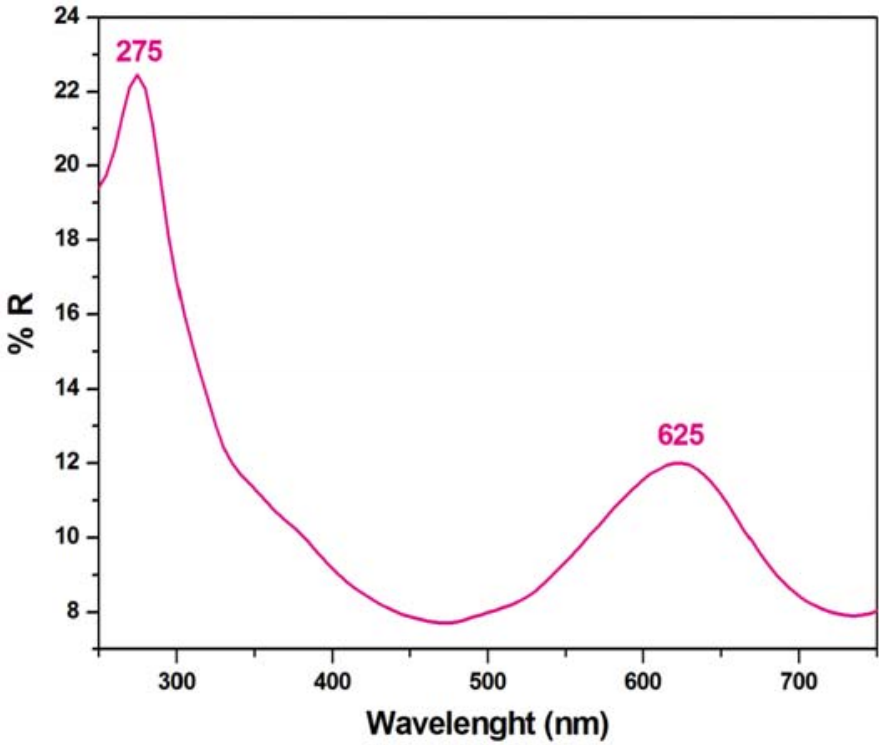

Fig. 9 
Table 1 Main interatomic distances $(\AA)$ and angles $\left(^{\circ}\right)$ of $\left(\mathrm{C}_{6} \mathrm{H}_{18} \mathrm{~N}_{3}\right)_{4}\left[\mathrm{CuCl}_{5}\right]_{2}\left[\mathrm{CuCl}_{4}\right]_{3}$ $1.42\left(\mathrm{H}_{2} \mathrm{O}\right)$.

\begin{tabular}{|c|c|c|c|}
\hline \multicolumn{4}{|l|}{ Inorganic anion } \\
\hline $\mathrm{Cul}-\mathrm{Cl} 6$ & $2.2888(5)$ & $\mathrm{Cu} 2-\mathrm{C} 15^{\mathrm{iii}}$ & $2.3008(5)$ \\
\hline $\mathrm{Cu} 1-\mathrm{Cl}^{\mathrm{i}}$ & $2.3160(4)$ & $\mathrm{Cu} 2-\mathrm{Cl} 5$ & $2.3009(5)$ \\
\hline $\mathrm{Cu} 1-\mathrm{Cl} 9$ & $2.3160(4)$ & $\mathrm{Cu} 3-\mathrm{Cl10}^{\mathrm{iv}}$ & $2.2402(4)$ \\
\hline $\mathrm{Cu} 1-\mathrm{Cl} 4$ & $2.3421(5)$ & $\mathrm{Cu} 3-\mathrm{Cl10}$ & $2.2402(4)$ \\
\hline $\mathrm{Cu} 1-\mathrm{Cl} 7$ & $2.7023(5)$ & $\mathrm{Cu} 3-\mathrm{Cl1} 1^{\mathrm{iv}}$ & $2.2650(4)$ \\
\hline $\mathrm{Cu} 2-\mathrm{Cl} 8^{\mathrm{ii}}$ & $2.2675(5)$ & $\mathrm{Cu} 3-\mathrm{Cl1} 1$ & $2.2650(4)$ \\
\hline $\mathrm{Cu} 2-\mathrm{Cl} 8$ & $2.2676(5)$ & & \\
\hline $\mathrm{Cl} 6-\mathrm{Cu} 1-\mathrm{Cl}^{\mathrm{i}}$ & $91.474(10)$ & $\mathrm{Cl} 8^{\mathrm{ii}}-\mathrm{Cu} 2-\mathrm{C} 15^{\mathrm{iii}}$ & 90.0 \\
\hline $\mathrm{Cl} 6-\mathrm{Cu} 1-\mathrm{Cl} 9$ & $91.475(10)$ & $\mathrm{Cl} 18-\mathrm{Cu} 2-\mathrm{Cl}^{\text {iii }}$ & 90.0 \\
\hline $\mathrm{C} 19^{\mathrm{i}}-\mathrm{Cu} \mathrm{l}-\mathrm{Cl9}$ & $162.99(2)$ & $\mathrm{Cl} 18^{\mathrm{ii}}-\mathrm{Cu} 2-\mathrm{Cl} 5$ & 90.0 \\
\hline $\mathrm{Cl} 6-\mathrm{Cu} 1-\mathrm{Cl} 4$ & $178.711(19)$ & $\mathrm{C} 18-\mathrm{Cu} 2-\mathrm{Cl} 5$ & 90.0 \\
\hline $\mathrm{C} 19 \mathrm{i}-\mathrm{Cu} 1-\mathrm{Cl} 4$ & $88.338(10)$ & $\mathrm{Cl}^{\mathrm{iii}}-\mathrm{Cu} 2-\mathrm{Cl} 5$ & 180.0 \\
\hline $\mathrm{C} 19-\mathrm{Cu} 1-\mathrm{Cl} 4$ & $88.337(10)$ & $\mathrm{Cl1} 0^{\mathrm{iv}}-\mathrm{Cu} 3-\mathrm{Cl10}$ & $136.05(2)$ \\
\hline $\mathrm{Cl} 6-\mathrm{Cu} 1-\mathrm{Cl} 7$ & $94.989(18)$ & $\mathrm{C} 110^{\mathrm{iv}}-\mathrm{Cu} 3-\mathrm{Cl1} 1^{\mathrm{iv}}$ & $99.367(15)$ \\
\hline $\mathrm{C} 19^{\mathrm{i}}-\mathrm{Cu} 1-\mathrm{Cl} 7$ & $98.213(10)$ & $\mathrm{Cl} 10-\mathrm{Cu} 3-\mathrm{Cl}_{1} 1^{\mathrm{iv}}$ & $100.144(15)$ \\
\hline $\mathrm{Cl} 9-\mathrm{Cu} 1-\mathrm{Cl} 7$ & $98.214(10)$ & $\mathrm{Cl1} 0^{\mathrm{iv}}-\mathrm{Cu} 3-\mathrm{Cl1} 1$ & $100.142(15)$ \\
\hline $\mathrm{Cl} 4-\mathrm{Cu} 1-\mathrm{Cl} 7$ & $86.300(17)$ & $\mathrm{Cl} 10-\mathrm{Cu} 3-\mathrm{Cl} 11$ & $99.366(15)$ \\
\hline $\mathrm{C} 18{ }^{\mathrm{ii}}-\mathrm{Cu} 2-\mathrm{Cl} 8$ & 180.0 & $\mathrm{Cl11} 1^{\mathrm{iv}}-\mathrm{Cu} 3-\mathrm{Cl11}$ & $126.15(2)$ \\
\hline
\end{tabular}

Symmetry codes: (i) $-x, y, z$; (ii) $-x,-y,-z+2$; (iii) $x,-y,-z+2$; (iv) $x,-y+1,-z+1$.Table 2 Bond length $(\AA)$ and angles $\left(^{\circ}\right)$ in the hydrogen bonding scheme of $\left(\mathrm{C}_{6} \mathrm{H}_{18} \mathrm{~N}_{3}\right)_{4}\left[\mathrm{CuCl}_{5}\right]_{2}\left[\mathrm{CuCl}_{4}\right]_{3}$ $1.42\left(\mathrm{H}_{2} \mathrm{O}\right)$.

\begin{tabular}{|c|c|c|c|c|}
\hline$D-H \cdots A$ & D-H & $\mathbf{H} \cdots A$ & $D \cdots A$ & $D-\mathbf{H} \cdots A$ \\
\hline $\mathrm{O} 1-\mathrm{H} 1 E \cdots \mathrm{Cl1} 1^{\mathrm{iv}}$ & 0.85 & 2.45 & $3.1523(7)$ & 141 \\
\hline $\mathrm{N} 1-\mathrm{H} 1 A \cdots \mathrm{C} 111^{\mathrm{v}}$ & 0.91 & 2.65 & 3.4783 (14) & 152 \\
\hline $\mathrm{N} 1-\mathrm{H} 1 B \cdots \mathrm{Cl} 5$ & 0.91 & 2.63 & $3.3679(13)$ & 139 \\
\hline $\mathrm{N} 1-\mathrm{H} 1 B \cdots \mathrm{Cl} 8$ & 0.91 & 2.63 & $3.3342(13)$ & 135 \\
\hline $\mathrm{C} 1-\mathrm{H} 1 C^{\cdots} \mathrm{Cl}^{\mathrm{vi}}$ & 0.99 & 2.61 & $3.5718(15)$ & 164 \\
\hline $\mathrm{C} 1-\mathrm{H} 1 D \cdots \mathrm{Cl} 4$ & 0.99 & 2.89 & $3.5842(15)$ & 128 \\
\hline $\mathrm{N} 2-\mathrm{H} 2 \cdots \mathrm{C} 14$ & 1.00 & 2.49 & $3.2886(12)$ & 136 \\
\hline $\mathrm{N} 2-\mathrm{H} 2 \cdots \mathrm{C} 19$ & 1.00 & 2.36 & 3.1728 (12) & 137 \\
\hline $\mathrm{C} 2-\mathrm{H} 2 A \cdots \mathrm{C} 16^{\mathrm{vii}}$ & 0.99 & 2.91 & $3.8970(15)$ & 175 \\
\hline $\mathrm{C} 2-\mathrm{H} 2 B \cdots \mathrm{C} 111^{\mathrm{v}}$ & 0.99 & 2.75 & $3.6070(15)$ & 145 \\
\hline $\mathrm{C} 4-\mathrm{H} 4 A \cdots \mathrm{Cl1} 0^{\mathrm{v}}$ & 0.99 & 2.74 & $3.5888(15)$ & 144 \\
\hline $\mathrm{C} 4-\mathrm{H} 4 B \cdots \mathrm{O} 1^{\text {viii }}$ & 0.99 & 2.33 & $3.249(2)$ & 154 \\
\hline $\mathrm{C} 5-\mathrm{H} 5 A \cdots \mathrm{Cl} 10$ & 0.99 & 2.72 & $3.5515(14)$ & 142 \\
\hline $\mathrm{C} 5-\mathrm{H} 5 B \cdots \mathrm{C} 110^{\mathrm{v}}$ & 0.99 & 2.79 & $3.5967(15)$ & 139 \\
\hline $\mathrm{C} 5-\mathrm{H} 5 B \cdots \mathrm{Cl} 11^{\mathrm{ix}}$ & 0.99 & 2.90 & $3.7672(14)$ & 147 \\
\hline C6-H6 $A \cdots \mathrm{Cl}^{\mathrm{vii}}$ & 0.99 & 2.70 & $3.6504(15)$ & 160 \\
\hline $\mathrm{C} 6-\mathrm{H} 6 B \cdots \mathrm{C} 19^{\text {vii }}$ & 0.99 & 2.94 & 3.4845 (14) & 116 \\
\hline $\mathrm{C} 3-\mathrm{H} 3 A \cdots \mathrm{Cl} 7$ & 0.99 & 2.93 & $3.8363(15)$ & 153 \\
\hline $\mathrm{C} 3-\mathrm{H} 3 B \cdots \mathrm{C} 111^{\mathrm{x}}$ & 0.99 & 2.87 & $3.6820(16)$ & 140 \\
\hline $\mathrm{N} 3-\mathrm{H} 3 C \cdot \cdots \mathrm{C} 18^{\mathrm{vii}}$ & 0.91 & 2.64 & $3.2309(12)$ & 123 \\
\hline $\mathrm{N} 3-\mathrm{H} 3 C \cdots \mathrm{C} 110$ & 0.91 & 2.51 & $3.3333(13)$ & 151 \\
\hline $\mathrm{N} 3-\mathrm{H} 3 D^{\cdots} \cdot \mathrm{Cl} 7^{\mathrm{vii}}$ & 0.91 & 2.25 & $3.1548(13)$ & 176 \\
\hline $\mathrm{N} 3-\mathrm{H} 3 E \cdots \mathrm{Cl} 4$ & 0.91 & 2.51 & $3.2312(13)$ & 137 \\
\hline $\mathrm{N} 3-\mathrm{H} 3 E \cdots \mathrm{C} 19$ & 0.91 & 2.58 & $3.3346(12)$ & 141 \\
\hline
\end{tabular}

Symmetry codes: (iv) $x,-y+1,-z+1$; (v) $-x+1 / 2, y,-z+3 / 2$; (vi) $-x,-y+1 / 2, z+1 / 2$; (vii) $x, y+1 / 21 / 2$, $-z+3 / 2$; (viii) $x, y-1 / 2,-z+3 / 2$; (ix) $-x+1 / 2,-y+1, z+1 / 2$; (x) $x,-y+1 / 2, z+1 / 2$. 
Table 3 Nature of contacts on the Hirshfeld surface around the cation, the three $\mathrm{Cu}$ and eight independent $\mathrm{Cl}^{-}$moieties. The second row shows the chemical contents $S_{x}$ on the surface. N $(0.4 \%)$ and $\mathrm{C}(1.6 \%)$ species are very rare on the surface and are omitted in the Table. The actual contacts $C_{x y}$ and their enrichment ratios $E_{x y}$ are then shown. The $E_{x y}$ values are obtained from the ratio $C_{x y} / R_{x y}$, where $R_{x y}$ are the equiprobable contacts. The major contacts $\left(C_{x y}>20 \%\right)$ are in bold. The enrichment values significantly larger than unity are in bold. Underlined enrichment values refer to the major disfavored contacts for which $R_{x y}>4 \%$.

\begin{tabular}{|c|ccccc|}
\hline & $\mathrm{Cl}$ & $\mathrm{Ho} / \mathrm{n}$ & $\mathrm{O}$ & $\mathrm{Hc}$ & $\mathrm{Cu}$ \\
\hline \% surface & 42.6 & 18.3 & 2.8 & 22.7 & 11.7 \\
\hline $\mathrm{Cl}$ & 4.9 & & $C_{x y} \%$ & contacts & \\
$\mathrm{Ho} / \mathrm{n}$ & $\mathbf{2 4 . 2}$ & 0.3 & & & \\
$\mathrm{O}$ & 0.6 & 0.0 & 0.0 & 2.6 & \\
$\mathrm{Hc}$ & $\mathbf{2 8 . 0}$ & 5.8 & 3.2 & 3.1 & 0.0 \\
$\mathrm{Cu}$ & $\mathbf{2 3 . 2}$ & 0.5 & 0.0 & Enrichment & \\
$\mathrm{Cl}$ & 0.27 & & $E_{x y}$ & & \\
$\mathrm{Ho} / \mathrm{n}$ & $\mathbf{1 . 5 6}$ & 0.08 & & $\underline{0.50}$ & 0.00 \\
$\mathrm{O}$ & 0.26 & 0.00 & 0.00 & $\underline{0.58}$ & \\
$\mathrm{Hc}$ & $\mathbf{1 . 4 5}$ & $\underline{0.70}$ & $\mathbf{2 . 4 7}$ & & \\
$\mathrm{Cu}$ & $\mathbf{2 . 3 4}$ & 0.12 & 0.00 & &
\end{tabular}

